\title{
MODERN THAI POETICS: PRIDE AND PURPOSE IN MODERN POETRY
}

\section{Suchitra Chongstitvatana ${ }^{1}$}

\begin{abstract}
The study aims to consider the nature of modern Thai poetics, in particular, poetry concerning the expression or declaration of the poet's sense of pride and purpose or role as a poet.

This type of poetry has been an important part of Thai literary convention since the Ayuddhya period (more than 200 years). Through the long history of poetry, this convention still holds an obvious influence over contemporary poets of today, as can be seen in the works of various major poets.
\end{abstract}

The study will cover the works of Ujjeni, Angkhan Kalayanaphong, Naowarat Phongphaibun, Phaiwarin Khaongam, Saksiri Misomsuep and Raekham Pradoikhom. These poets, despite their different world-views, compose poetry of 'declaration' in their works in various styles. Some poets emphasize their philosophy of poetic beauty and some emphasize their 'ideal' and 'pride' as poets.

Through an investigation of the works of these poets, we will see how the poets view themselves, what they consider to be

1 Department of Thai, Faculty of Arts, Chulalongkorn University. 'ideal' in their works and their 'obligation' to others.

From a thorough study, we should be able to establish to what extent Thai poetics have changed and whether these changes affect the literary judgement of the readers, and in turn create a new foundation for a modern convention relative to the present and the future.

\section{Introduction}

The paper aims to consider the nature of modern Thai poetics --in particular, poetry concerning the expression or declaration of the poet's pride and purpose or role as a poet.

The study will cover the works of prominent contemporary Thai poets Ujjeni, Angkhan Kalayanaphong, Naowarat Phongphaibun, Phaiwarin Khaongam, Saksiri Misomsuep and Raekham Pradoikhom.

\section{Classical Thai Poetics: The Importance of Literary Conventions}

Students of Thai literature, when making themselves familiar with Thai classical poetry, soon discover the importance of literary conventions in the texts. This importance can be clearly illustrated through the texts of poetry from the early Ayuddhya period to the early Rattanakosin 
period (C15th - C19th). Both the form and the content of the work is highly 'controlled' by the conventions and yet it is surprising to observe how the poets seem to acquiesce to rather than rebel against these conventions.

It is believed that Thai literary conventions are much influenced by Indian poetics, i.e. by Pali and Sanskrit literature. However, it is not the concern of this paper to trace or to prove these beliefs.

Our concern here is the part of Thai literary conventions that relates to the poet's 'declaration' of his name, the purpose of the work and the pride of the poet as the creator of great work.

These conventions appear in masterpieces of Thai poetry such as works by YuanPhai, Lilit Phra Lo, Kamsuan Khlong Dan, Prince Thammathibet and Sunthon Phu.

If we trace back to the Pali literature, we may find the origin of this convention. It is a Buddhist custom for a poet to compose a Pranamma Katha as a prologue to his work, paying homage to the Three Sacred Gems and giving the name and position of the poet or some detail of the story of Lord Buddha's life. As an epilogue, the poet usually composes Uthit Katha, declaring the purpose of his work and expressing a dedication of the work.

It is believed that poets in the early Ayuddhya period may have been influenced by this Buddhist custom in Pali literature through the great poets of Lanna, as the two kingdoms of Ayuddhya and Lanna were closely related culturally throughout that period.

\section{Modern Thai Poetry and Modern Conventions}

The focus of this study is to investigate the convention of modern poets regarding the 'declaration' of their pride and purpose in their works.

\section{Ujjeni: Poetry of Inspiration for a Better World.}

Ujjeni is a senior poet in the domain of modern poetry. Her work, though not in abundance, is a strong influence on the younger generation of poets. In her unique and celebrated collection of poetry Khop Fa Khlip Thong (The Golden Horizon), we find the poem "Higher Up". This poem is an exquisite description of the grace and the beauty of poetry in the poet's mind, as well as a proud declaration of the poet's commitment to others.

\section{Higher Up}

Like a crystal stream of light

Smiling to admire the radiant down A brilliant spring dancing up high

Like a rainbow descending the sky

Higher up, higher up, undaunted, Devotion and passion immeasurable Under fierce sunshine or heavy rain The heart of lasting faith prevails!

The pure crystal spring smiling Dancing to the soft sweet breeze Delicate as a wild flower Listening to the breeze's lullaby!

When night falls with all stars a-shining The crystal spring overcomes the stars Glittering with divine radiance Mocking brillant diamonds of the sky! 
Its sweetness and gentleness A divine gift for the dark land Showering joys and delights around To quench and to cleanse all evils!

The pure heart of a poet As pure and as magnificent Aiming high for beauty and truth With integrity of a proud heart! Higher up, higher up Great goodness of sweet words A stream of lasting hope The poet's ever lasting love!

Ujjeni
from Khop Fa Khlip Thong
translated by
Suchitra Chongstitvatana

This text indicates that one of the main purposes of poetry is to use purity of the poet's heart to quench the thirst of the less fortunate and to cleanse all the evils of the 'dark land'.

The metaphor of poetry as a spring -so pure and powerful going up as high as heaven -is unique in Thai literary conventions and yet is not alien to the root of Thai culture where water is worshipped as the goddess of life- kindly giving to all with unbounded compassion.

This metaphor emphasizes the noble obligation of the poet to be an idealist with a brave virtuous heart. The creation of poetry, for the poet, is an act of benevolence to help change the world for the better.

When we consider the content of Ujjeni's works, we can clearly see that the message of benevolence is strongly conveyed throughout. She writes about the poor, the less fortunate and the idealists, using symbols from nature such as the sun, the moon, the star, the rain, the wind and the rainbow. Through these symbols, Ujjeni inspires the idealists to go on fighting and at the same time she consoles the less fortunate to keep faith in goodness and justice.

The beneficial aspect of poetry in the ideal betterment of the world is also emphasized differently in various works of later poets. One poet who passionately believes in the benevolence of the art of poetry is Angkhan Kalayanaphong.

\section{Angkhan Kalayanaphong: Poetry of Spiritual Salvation}

Among contemporary Thai poets, Angkhan is perhaps the most concerned about the commitment of poets and the 'sacredness' of the art of poetry.

He has composed a large number of poems with 'declarations' of his love and devotion to poetry. The following translation is from his first collection of poetry, Kawiniphon Khong Angkhan Kalayanaphong (Poetry of Angkhan Kalayanaphong).

\section{The Poet's Resolution}

The sky I wrap around me Keeping warm amidst cold nights The lights of glittering stars I savor As my daily bowl of rice The dews of heaven I drink To compose verse-streams Of ever lasting poetry!

The heart I sacrifice as a grave The soul roaming afar to heaven Searching divine bliss to the Earth To console the sand and the grass Rendering happiness and joys! 
I write to salvage the soul Amidst the torrent of fierce Time Life is a fleeting illusion Still my heart will defy all Shining with ever-lasting bliss!

My body will be burnt away Yet my poesie will remain How many lives I am born again A proud poet I will always be Glittering like invaluable gems!

The dance of letters is a pure joy As heavenly rain soothing the heart The soul soaring high to lands of dreams Savoring fragrances of this world And the next world of no end!

\section{Gladly I'll give up my life}

For a purely exquisite creation

The art of poetry shall be sacred

Like flowers of heaven falling down

To ever charm the world of ours!

\section{Angkhan Kalayanaphong 1959 Thonburi from Kawiniphon translated by Suchitra Chongstitvatana}

This poem is perhaps Angkhan's most famous work, though he later composed a similar poem with the same title (yet in a different verse form) in 1970 . We will concentrate first on this text of 1959 and then move on to consider other texts of the poet.

In the above poem, the poet describes clearly his pride and purpose or role as a poet. The beginning of the poem illustrates the poet's status as a 'nonordinary' human being. Angkhan's poet lives on divine and pure elements of nature such as starlight and dew, and his attire is simple and noble -the sky. He asks for no comfort but only for the freedom of his heart.

The reader is given the feeling that perhaps the poet considers himself almost as an ascetic who sacrifices and suffers for the good of others. He declares that his life is given to the art of poetry and he writes to 'salvage' the soul, perhaps his own soul, as well as the soul of humanity.

Yet the poet has a great pride for his devotion to being poet. He defies life and time with his poetry and aims at 'eternity' for his work.

As discussed earlier, it is not surprising or uncommon to wish for such 'eternity' as great poets in the past expressed a similar wish before in their works.

However, Angkhan may be the first poet to state explicitly that his poetry is so worthy of such 'eternity' because poetry is 'divine bliss' of heaven brought to the world by the poet. This 'divine bliss' is a gift for the world, especially for 'the sand and the grass' which are no doubt subtle symbols for the less-fortunate and underprivileged.

His passionate dedication is emphasized at the end of the poem when the poet declares that his life is a ready sacrifice for the 'sacred' continuation of the art of poetry.

The value the poet attaches to poetry is further emphasized in his later text (1975) of the same title when the poet proudly claims that he would refuse even to enter 
Nirvana in order to remain on earth to compose poetry for the Universe. ${ }^{2}$

By referring to Nirvana the poet is indirectly equating the merit of composing poetry to the highest merit of training oneself spiritually to enter Nirvana. Thus the main purpose of writing to 'salvage' the soul is clarified. The poet may salvage both his soul and the soul of humanity at the same time through his poetry.

Poetry becomes a means of spiritual betterment, almost like a religion and the 'sacred' aspect of poetry is lavishly described in all Angkhan's works.

\section{Naowarat Phongphaibun: Poetry of Spiritual Sweetness}

The poetry of Naowarat is the best evidence of the beneficial influence of 'conventions' on the creative works of modern poets. Naowarat makes perfect use of his admiration for great poets of the past especially Sunthon $\mathrm{Phu}$ and his distinctive style is appreciated in the exquisite melody and 'spiritual sweetness' of his works.

The following poem by Naowarat is a unique definition of what poetry is and how a real poet should write.

2 See Suchitra Chongstitvatana "The Green World of Angkhan Kalayanaphong: A vision on Nature and Environment", in Thai Literary Traditions, Chulalongkorn University Press, 1995, p.153.

$$
\text { Poetry }{ }^{3}
$$

Poetry is

A moment of a flower bud blooming

An inspiration, a dream, an ideal

A perfect skill of a word creator

A second language of emotions

$A$ recollected intensity of feelings

A liveliness of Truth

An exquisite and ever lasting

remembrance.

You are a poet

You must know beauty and harmony

Joyous and wondrous harmony

And insight of spiritual sweetness

You must create life from realities

Create words with poetic magic

Strongly rhyming hearts with hearts

Enslaving not poetry merely to words!
Naowarat Phongphaibun
from Phleng Khlui Phio
translated by
Suchitra Chongstitvatana

The first half of the poem consists of a series of definitions of poetry. These definitions reflect a deep influence of Thai literary conventions combined with the romantic characteristics of the poet's works.

When the poet says that poetry is 'a perfect skill of a word-creator', he is echoing the traditional concept of a poet as a creator of language or a sage in language use.

The metaphor of poetry as a second language of emotions may very well fit the idea that poetry, first and foremost, is purely concerned with feelings rather than intellect. This emphasis on the nature of

\footnotetext{
${ }^{3}$ The original text has no title. This title has been given by the translator.
} 
poetry is evident in all Thai poetry, especially classical poetry.

However, it is obvious that Naowarat is also influenced by the 'modern' ideology of his time when he says that poetry is 'a liveliness of Truth'. The Thai word for 'Truth' the poet uses here is 'Sajjatham' which has been quite a cliché in poetic diction since 1973 .

When Naowarat describes the qualities of a good poet, he emphasizes the spiritual aspect of poetry -sweetness and harmony both in the concrete form and the spiritual sense.

It is worth noticing that unlike Angkhan or Ujjeni, Naowarat's expression of the 'purpose' of his poetry is hardly explicit. Yet we can surely see the importance he attaches to the value of poetry -that it reaches beyond the beauty of words.

For Naowarat, a poet must have 'an insight of spiritual sweetness' which will enable him to express and create an 'essence' of poetry which is deeper and finer than the normal poetic beauty of words alone.

Thus, to a certain extent, it would not be wrong to say that the ultimate purpose of writing poetry is to perfect the poetic art to become a real poet, free from the burden of poetical rules and yet capable of exploiting the rules for the ultimately pure beauty of the spiritual sweetness of poetry.

Though Naowarat is deeply concerned about the social and political problems of Thai society, his work is at its best when he is dealing with 'spiritual and philosophical' beauty. Examples of his best work can be found in Kham Yad (Sweet Words), Phleng Khlui Phio (The
Flute Song), Chak Ma Chom Mueang (City Sojourn on the Horseback).

\section{Phaiwarin Khaongam: Poetry of Loving Hearts}

Another poet who seems to follow the 'poetic path' of Ujjeni, Angkhan and Naowarat is Phaiwarin Khaongam. The following two poems describe the philosophy of his work.

Gracious is my mind Creating joyous good for the land

I say my soul, making dreams come true Everything completed

I explore myself, my life

Giving light for dark nights

Creating Today for Tomorrow

Sprinkling love over the World

Soothing sufferings, sorrows,

Sharing, sharing all!

\section{More Than A Word Can Say}

A life passing away

A burning candle melting

Giving light of faith unfailing

One to another always!

$A$ heart of love and faith

Combining hearts to hearts

Together they compose

Poetry of loving hearts

My heart explores and questions

With all my soul my life

To know right and wrong

To know joys and sorrows

Thus I can only speak these verses A truly genuine self of mine Beyond the land and the sky afar May my poetry remain with Time. 
Phaiwarin Khaongam

from Kham Dai Cha Oei Dai Dang

Chai translated by

Suchitra Chongstitvatana

From these two poems, the influence of Ujjeni, Angkhan and Naowarat is quite evident. The poet values poetry as a divine gift that can soothe the world and, as an ever-lasting goodness that poets give to mankind.

In the poem More Than a Word Can Say, the poet emphasizes the word 'heart' or 'chai' in Thai. Thus the poet believes that the 'essence' of poetry lies in the noblesse and finesse of the heart when he says 'poetry of loving hearts'. This idea may be an echo of Naowarat's emphasis on 'spiritual sweetness' of poetry. Yet, Phaiwarin's metaphor of 'sprinkling love over the world' to soothe sufferings and sorrows is similar to the metaphors of Angkhan and Ujjeni.

The poet subtly expresses his pride in a conventional manner by wishing for his work to remain forever - "May my poetry remain with Time."

\section{Raekham Pradoikhom: Poetry of Desire's Fulfilment}

In his latest collection of poetry Nai Wela (In Time), Raekham opens his work with a prologue, expressing his pride and purpose or role as a poet as follows:

\section{Prologue}

To fulfil my desire do I write

With love and faith for poetic grace

Though my work may not last till the end of time

It will be of great power and virtuous charm
Enchanted with belles-lettres

It's the heart that writes poetry

It's the heart that labours

To create poetry of life!

May this work be a consolation of age

Let it be my work of pride

To bless my own heart and my life

I entrust this to the World of Letters!

\author{
Raekham Pradoikhom \\ from Nai Wela \\ translated by \\ Suchitra Chongstitvatana
}

Comparatively speaking, this prologue is the most conventional of all the texts discussed earlier. The poet expresses his love and his pride in a very explicit manner. He emphasizes the enchantment of belles-lettres which inspires the creation of poetry. This idea is expressed frequently throughout the long history of Thai poetry.

It is noteworthy that the poet expresses his pride in a disguise of 'modesty', a conventional manner employed by Thai poets in the past, especially those of the early Ayuddhya period.

The poet says that 'though his work may not last till the end of Time, it will be of great power and virtuous charm'. This is an echo of 'modesty' of great poets of the past.

Nevertheless, the 'purpose' the poet expressed here is twofold. One is to offer his work as a 'consolation' of the age. Another is to contribute to the world of belles-lettres or poetry.

The 'purpose' or role of the poet here seems to be quite 'natural' and 'personal' enough, yet it is still in line with the view 
of the other poets discussed earlier. Therefore, if the ultimate goal is to create a great art to fulfill one's own desire and love for poetry, composing poetry or perfecting the art of poetry appears to be an end in itself.

Nevertheless, this does not mean that Raekham's work is only concerned with the art of poetry. On the contrary, his poetry reflects a thorough observation of human nature in a very philosophical tone.

This can be seen even through the titles of his works such as Nam Phu Rung (Rainbow Spring), Din Nam Lom Fai (Earth, Water, Wind, Fire), and Nai Wela (In Time).

In Nai Wela, the poet observes human changes in various stages through timebirth, youth, old age and death and employs them as his theme. The philosophical tone in the work makes this modern collection of poetry rather solemn and the obvious influence of Buddhism appears in the rather conventional verse forms.

\section{Saksiri Misomsuep: Poetry of Purification}

Saksiri is an outstanding contemporary poet because he seems to be alone in succeeding to establish the beauty of 'free verse' and he has gained wide recognition for his creation. In his most famous work Mue Nan Si Khao (That Hand Is White), he declares the main idea of his work that 'only clean hands can create a clean world'.

The following poem appears as an epilogue in Mue Nan Si Khao. It is worth noticing that the poet deliberately composes this poem in the imitation of Khlong, a very formal verse form steeped in Thai literary conventions.

$$
\text { Epilogue }^{4}
$$

Why flowing downwards so low Aiming high to share heaven's delight Overflowing hills and wild plains

The water's dream is to cherish the Earth

The cherished earth is for lovely trees

The sacred sky is satisfied

To see the abundance greens below

To serve Spring passing by!

A radiant light illuminates the Earth

Glowing so divinely pure and bright

To grand mountains and humble grass

The secret of heaven's heart

And the grass' remembrance

Will you reveal your heart?

Silence and waiting in vain

Can it really be that your life here

Is only to satisfy your desires?

Leaves dancing to the song of breeze

Gentle waves of forest melody

Yellow leaves falling in melancholy

Letting go is perhaps the best remedy.

\section{Saksiri Misomsuep \\ from Mue Nan Si Khao \\ translated by \\ Suchitra Chongstitvatana}

The content of this epilogue subtly reveals the strong influence of Buddhist thought on the poet's part. The metaphors from nature and of poetry as an inspirational force for contemplation reflects the poet's purpose quite clearly, though indirectly. The poet's concern with the purifying nature of poetry may be an echo of his own deep inclination as a teacher and a Buddhist.

\footnotetext{
${ }^{4}$ The original text has no title. This title is given by the translator.
} 


\section{Pride and Purpose as Modern Thai Poetics}

From this discussion, it is clear that modern Thai poets' expression of pride and purpose in their works has been established as a 'modern' convention. Modern poets appear to take their role as poets very seriously. The pride and purpose they express in the work are inseparable.

This can be explained in two aspects. The first is the aspect of continuation of literary conventions of the past, where being a poet (in a written tradition) is a privilege of an elite who can read and write. Thus to create a literary work of value for specific purpose is naturally and rightfully a duty of any king or prince. Especially, if the 'specific' purpose of the work has something in connection with religious belief or a part of a ceremony or celebration, as is usually the case of Thai classical poetry.

If the work has religious influence, the poet usually views it as an offering and usually makes a wish of attaining 'Nirvana' as the highest rewards for his effort.

Thus it is understandable that poets of the past should take a great pride in their own privileged knowledge and in their artistic creation. This pride is rightly justified and can hardly be blamed (even by Buddhist standards of modesty) because it is a pride as a means towards a noble end.

On the other hand, one dominant purpose of poetic creation from the past to the present is perhaps to attain perfection in the art of poetry.
This dominant purpose can be seen even in the work of modern poets who have a very strong determination to better the world or to 'salvage' the soul.

Modern poets, in a society which is very different from the past, seem to share the same desire to immortalize the art of poetry through their works.

Though the status of modern poets today cannot in any sense be compared to that of the past, modern poets still view themselves more or less as 'sages' or 'spiritual leaders' of society.

By accepting these roles of prestige, yet without any patronage as in the past, modern poets are in fact in a very vulnerable situation. They cannot really work for material gain nor for any specific group of readers. They turn to their own ideals and their own inclinations as a refuge.

Thus, among modern Thai poets we see a variety of styles and expressions, but a shared view as to the ultimate goal of doing good for society.

The declaration of the poets' pride and purpose in their works appears to be an 'overture' for the reader, who will either be drawn to the poet or be put off by this poem of declaration.

As long as poets can uphold their prestige of working for their own spiritual fullfilment or their ideals alone, this 'modern' convention will still hold a strong influence in Thai literary conventions.

This convention could be a sacred means through which poets can preserve their 'pride and purpose' as poets. Consequently this convention could, in turn, cherish 
pride and inspire purpose in the hearts and minds of readers of poetry in the present and future.

\section{References}

Angkhan Kalayanaphong. 1970. Kawiniphon Khong Angkhan Kalayanaphong, 2nd ed.. Bangkok.

Kawi, 2nd ed.. Bangkok.
. 1991. Lam Nam Phu

Kradueng, 3rd ed.. Bangkok.

Manas Chitakasem (ed.) 1995. Thai Literary Traditions. Bangkok.

Naowarat Phongphaibun. 1980. Phleng Khlui Phio, 2nd ed.. Bangkok.

Phaiwarin Khaongam. 1986. Kham Dai Cha Oei Dai Dang Chai. Bangkok.

Raekham Pradoikhom. 1999. Nai Wela, 2nd ed.. Bangkok.

Saksiri Misomsuep. 1988. Mue Nan Si Khao. Bangkok.

Ujjeni. 1989. Khop Fa Khlip Thong, Karat. Bangkok.

\section{Manusya : Journal of Humanities}

Vol.3 No.1 (March 2000)

\section{Krisdawan Hongladarom}

Competing Discourses on Hilltribes:

Media Representation of Ethnic Minorities in Thailand

\section{Ubonrat Siriyuvasak}

The Media, Cultural Politics and the Nation-State

\section{Bussakorn Sumrongthong}

Homrong Sakura: A Composition for the New Millennium

Jeffrey Gilliam

Brecht and Songs

Wijit Wongwareethip

Sexuality: Reading through Agony Columns

\section{Duncan McCargo}

Reforming the Thai Print Media

Trisilpa Boonkhachorn

The Development and Trends of Literary Studies in Thailand

** ALL BACK ISSUES ARE STILL AVAILABLE ** 